\title{
EVALUATION OF ENDOSCOPIC COMBINED INTRARENAL SURGERY IN MANAGEMENT OF COMPLEX RENAL STONES
}

Hazem Rashad, Akram Assem, Mohamed Hamed Ramadan

Department of Genitourinary surgery, Alexandria University, Egypt

\section{Introduction}

- Percutaneous nephrolithotomy PCNL has become the gold standard for the management
of large or complex Renal stones. Retrograde intrarenal surgery (RIRS) has been recently
introduced as highly effective technique in management of renal stones specially with
anomalous kidney and in coagulopathies.
- Nowadays, achieving a high stone free rate with a lower morbidity have led RIRS to
become a commonly used and important treatment modality for management of renal
stones less than $2 \mathrm{~cm}$.
- Supine Valdivia position has been modified multiple times till we reached more
ergonomic Galdakao-modified supine Valdivia (GMSV) position.
- The GMSV position optimally supports ECIRS (Endoscopic Combined IntraRenal
Surgery), a novel simultaneous combined antegrade and retrograde approach to the upper
urinary tract for the treatment complex urolithiasis.
- Multiple stones in different parts of pelvicalyceal system which are supposed to need
multiple punctures to clear all the stones using classical prone PCNL was always a
concern for the surgeon due to morbidity and time consumption for multiple tracks.
ECIRS in GMSV position can be introduced as a new effective, safe and time saving
technique to solve this problem specially with associated ureteral stones.

\section{Aim of the work}

Aim of the study to evaluate the efficacy and safety of ECIRS in management of complex renal stones.

\section{Subjects and Methods}

- Study was prospectively conducted and included 22 cases, whom underwent ECIRS
using GMSV position for management of complex renal stones in the Department of
Genitourinary Surgery, Alexandria Main University Hospital.
Demographic data, stone and kidney characters, operative time, stone free rate,
intraoperative and postoperative complications were recorded.
Simultaneous antegrade and retrograde approaches to access complex kidney stone in
GMSV position and remove it in a single session with single nephrotomy track.

\begin{tabular}{|c|c|}
\hline \multicolumn{2}{|l|}{$\begin{array}{l}\text { The whole pelvic portion of the stone w } \\
\text { calyx using antegrade access and this cr } \\
\text { work between two surgeons using simult } \\
\text { remove the rest of the stones. }\end{array}$} \\
\hline \multicolumn{2}{|l|}{ Results } \\
\hline \multicolumn{2}{|c|}{$\begin{array}{l}\text { - The mean stone size was } 5.54( \pm 1.31) \mathrm{CM} \text {. } \\
\text { - The stone free rate SFR was }(86.4 \%) \text { and }(95.4 \%) \text { after reintervension. } \\
\text { - The mean operative time was } 72.64( \pm 23.92) \text { minutes which is relatively short. } \\
\text { - Complication rate was } 9.1 \% \text { of cases and all of these complications were of grade } 2 \\
\text { with mild postoperative pain and minimal analgesia requirements. }\end{array}$} \\
\hline \multicolumn{2}{|c|}{ Table: Distribution of the studied cases according to different parameters $(\mathrm{n}=22)$} \\
\hline \multicolumn{2}{|l|}{ Operative time (min.) } \\
\hline $\begin{array}{l}\text { Operative time (min.) } \\
\text { Mean } \pm \text { SD. } \\
\text { Median (Min. }- \text { Max.) }\end{array}$ & $\begin{array}{l}72.6 \pm 23.9 \\
65(40-135)\end{array}$ \\
\hline \multicolumn{2}{|l|}{$\begin{array}{l}\text { Radiation (min.) } \\
\text { Mean } \pm \text { SD. }\end{array}$} \\
\hline $\begin{array}{l}\text { Mean } \pm \text { SD. } \\
\text { Median (Min }- \text { Max })\end{array}$ & $2.7 \pm 0.9$ \\
\hline $\begin{array}{l}\text { Median (Min. - Max.) } \\
\text { DJ }\end{array}$ & $\frac{3(1-4.4)}{22(100 \%)}$ \\
\hline Nephrostomy & $22(100 \%)$ \\
\hline $\begin{array}{l}\text { Stone free rate }(\%) \\
\text { Stone free } \\
\text { Residual stones need more intervention }\end{array}$ & $\begin{array}{l}19(86.4 \%) \\
3(13.6 \%)\end{array}$ \\
\hline \multicolumn{2}{|l|}{ Mode of re-intervention } \\
\hline & $19(86.4 \%)$ \\
\hline PCNL & $2(9.1 \%)$ \\
\hline $\begin{array}{l}\text { ESWL } \\
\text { Time of PCN (hrs.) }\end{array}$ & Time of PCN (hrs.) \\
\hline $\begin{array}{l}\text { Mean } \pm \text { SD. } \\
\text { Median (Min. - Max.) } \\
\text { Mode }\end{array}$ & $\begin{array}{l}13.4 \pm 29.6 \\
6(6-144) \\
6\end{array}$ \\
\hline \multicolumn{2}{|l|}{$\begin{array}{l}\text { Time of DJ (days) } \\
\text { Mean } \pm \text { SD. }\end{array}$} \\
\hline Mean \pm SD. & $11.8 \pm 5.9$ \\
\hline $\begin{array}{l}\text { Median (Min. - Max.) } \\
\text { Mode }\end{array}$ & $\begin{array}{l}10(10-30) \\
10\end{array}$ \\
\hline Hospital stay (day) & \\
\hline $\begin{array}{l}\text { Mean } \pm \text { SD. } \\
\text { Median (Min. - Max.) }\end{array}$ & $\begin{array}{l}1.5 \pm 1.4 \\
1(1-7)\end{array}$ \\
\hline $\begin{array}{l}\text { Median (Min. - Mlax.) } \\
\text { Mode }\end{array}$ & \\
\hline
\end{tabular}

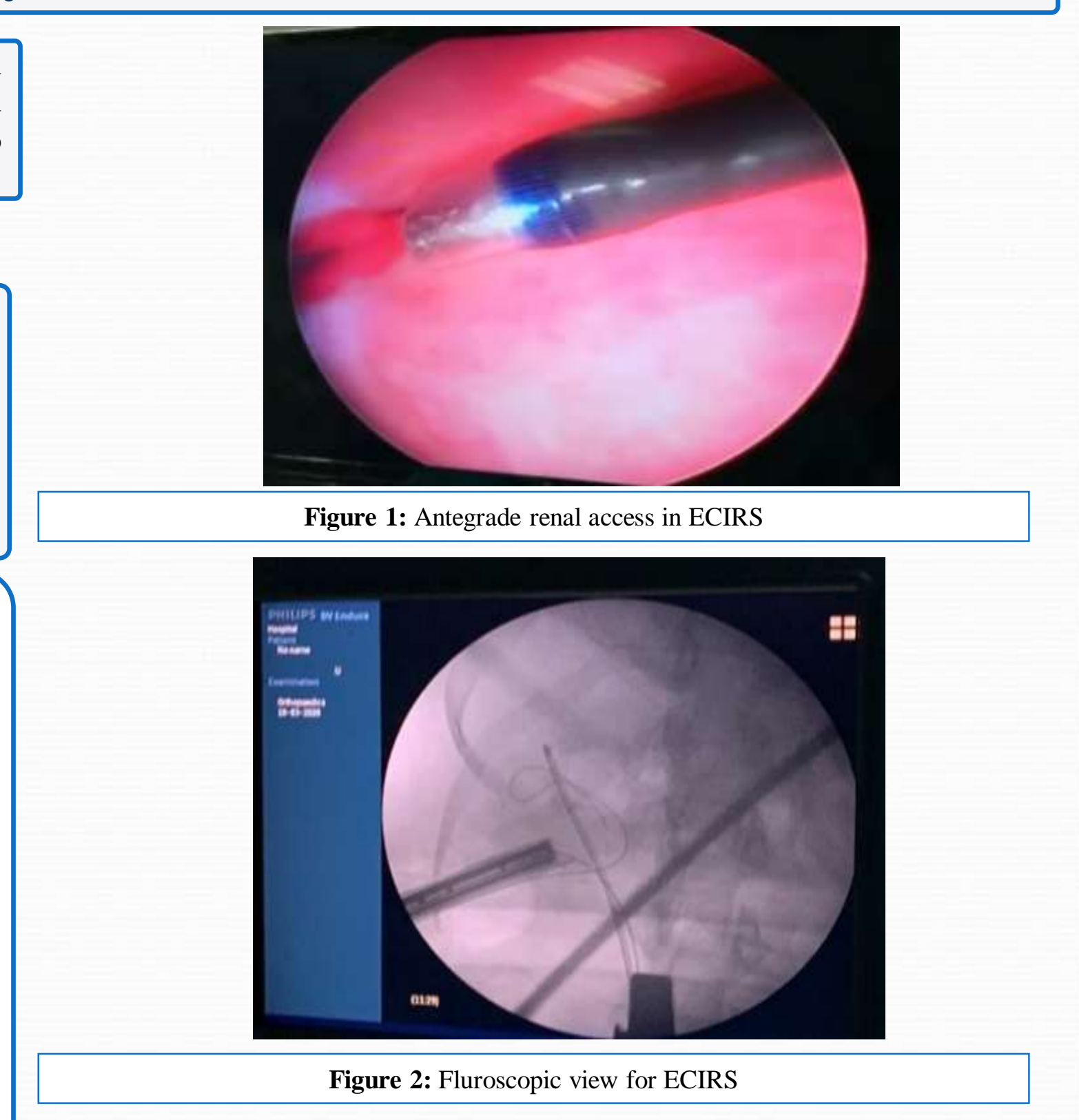

\section{Conclusion}

- ECIRS can be introduced as a highly effective, safe and time saving technique for the management of complex renal stones.
2021@Alexandria Faculty of Medicine CC-BY-NC 